$$
\begin{aligned}
& \text { SF } 258 \\
& N 5 C_{6} \\
& 19 / 3
\end{aligned}
$$



INITED STATES PUBLIC HEALTH SERVICE

\section{COMMISSION ON MILK STANDARDS}

SECOND REPORT OF THE COMMISSION ON MILK STANDARDS APPOINTED BY THE NEW YORK MILK COMMITTEE

CONTAINING RESOLUTIONS ADOPTED AT THE MEETING IN RICHMOND, VA., MAY 2-3, 1913

REPRINT No. 141 .

FROM THE

PUBLIC HEALTH REPORTS

AUGUST 22, 1913

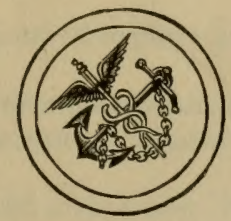

WASHINGTON

GOVERNMENT PRINTING OFFICE 1913 
1 SF $35^{58}$
$N_{5} C^{6}$

1913

D. OF $\mathrm{B}$.

SEP 201913

$$
\therefore \vdots
$$




\title{
COMMISSION ON MILK STANDARDS.
}

\section{SECOND REPORT ${ }^{1}$ OF THE COMMISSION ON MILK STANDARDS APPOINTED BY THE NEW YORK MILK COMMITTEE.}

\author{
[Reprint from the Public Health Reports, Vol. XXVIII, No. 34, August 22, 1913.]
}

\section{INTRODUCTION.}

\section{PERSONNEL.}

The New York Milk Committee, which is a voluntary organization working in the interests of improving the milk supply of New York City decided, in March, 1911, to appoint a commission on milk standards. The men who compose the commission are as follows:

Dr. W. A. Evans, professor preventive medicine, Northwestern University; health editor, Chicago Tribune, Chicago, Ill., chairman.

Dr. B. L. Arms, assistant, department biology and public health, Massachusetts Institute Technology, Boston, Mass.

Dr. John F. Anderson, Director Hygienic Laboratory, United States Public Health Service, Washington, D. C., vice chairman.

Prof. H. W. Conn, director bacteriological laboratory, Connecticut State Board of Health; department of biology, Wesleyan University, Middletown, Conn.

Dr. E. C. Levy, health officer, Richmond, Va.

Dr. A. D. Melvin, Chief Bureau of Animal Industry, United States Department of Agriculture, Washington, D. C.

Dr. William H. Park, director of laboratories, Department of Health of New York City; professor of bacteriology and hygiene, New York University, New York City.

Mr. Raymond A. Pearson, president State College of Agriculture, Ames, Iowa.

Dr. M. P. Ravenel, director hygienic laboratory, University of Wisconsin, Madison, Wis.

Prof. M. J. Rosenau, department of hygiene and preventive medicine, Harvard Medical School, Boston, Mass.

Mr. Chester H. Wells, health officer, Montclair, N. J.

Prof. Henry C. Sherman, department of chemistry, Columbia University, New York City.

Dr. L. L. Van Slyke, department of chemistry, New York Agricultural Experiment Station, Geneva, N. Y.

Dr. Charles E. North, consulting sanitarian; member New York Milk Committee, New York, secretary.

Dr. J. N. Hurty, secretary State board of health, Indianapolis, Ind. Pa.

Dr. Joseph S. Neff, director Department Public Health and Charities, Philadelphia,

Dr. John S. Fulton, director State department of health, Baltimore, Md. 


\section{ORIGIN AND ORGANIZATION.}

The appointment of this commission was the direct result of the observation of the New York Milk Committee that there was great incompleteness and lack of uniformity in the milk standards, milk ordinances, and rules and regulations of public health authorities throughout the country for the control of public milk supplies. There was a need that health officers be furnished conclusions drawn from large experience and mature judgment and that ordinances should be as free from erroneous positions and as uniform as possible.

A special committee of the New York Milk Committee was appointed to consider names of more than 200 men of prominence in medicine, sanitation, public health, and laboratory work, particularly those recognized as authorities on the milk question. Since regulations are based on standards and standards are based chiefly on laboratory analyses, the subcommittee selected 20 names of men distinguished for their knowledge of the bacteriological and chemical examination of milk and for the enforcement of standards based on such laboratory examinations. Two of those chosen declined to serve and another resigned after the first meeting, so that there were 17 members who have taken an active part in the work of the commission.

\section{PURPOSES.}

While this commission was created by and its expenses were borne by the New York Milk Committee, it has not been the intention of that committee that the commission should have the New York City milk problem solely in mind. It was desired that the commission should make recommendations that might be adopted by any city or town in the country.

\section{MEETINGS.}

The first meeting of the commission was held in the New York Academy of Medicine on May 22, 1911. The chief work of that meeting consisted in a general discussion of the scope of the commission's purpose and the appointment of a number of standing committees to which the several divisions of the work were assigned. The subjects included bacteriological standards, chemical standards, grades and classes of milk, standard ordinances, laws, and licenses, and new questions.

- The second meeting of the commission was held at the New York Academy of Medicine on October 5 and 6, 1911, at which time the reports of the standing committees were received and modified, and the major part of them tentatively adopted. Special committees were appointed at this time to consider certain specific matters which were presented and final action on all matters was deferred until the third and final meeting. 
The third meeting of the commission was held in Homer, N. Y., on January 25, and at the New York Academy of Medicine, January 26 and 27, 1912. The commission visited Homer in order that the members might inspect the central station and the dairy farms of the New York Dairy Demonstration Co. as a means of helping them to form a correct judgment of the relative value to be given to methods and equipment in the rules and regulations that they might recommend.

At this meeting it was voted to publish the first report of the commission, with an understanding that one year later the commission would meet for the purpose of reconsidering this report and modifying it in such manner as deemed advisable. In consonance with this resolution the first report was submitted to the Public Health Service and was publised by that Service in the Public Health Reports, Volume XXVII, No. 19, May 10, 1912; 70,000 copies were distributed.

The fourth meeting was held in Chicago, October 29 and 30, 1912, at the time of the National Dairy Show. At this meeting the commission attended the annual convention of the International Milk Dealers' Association and took part in a discussion of classification of milk and milk standards. The largest milk dealers of the United States and Canada were present.

The fifth meeting of the commission was held in Richmond, Va., on May 2 and 3, 1913, at the Hotel Jefferson. The purpose of the commission in visiting Richmond was to inspect the dairies supplying milk to a city of moderate size, surrounded by farms which have been raised to a condition of sanitary excellence.

It was resolved at the fifth meeting to publish an amended report which would include certain new matters and from which some of the material in the first report would be eliminated. The commission voted to preface its report by a preamble of explanation showing the reasons for the commission's action on the matters in the report.

P R E A M B L E.

NEED OF MILK CONTROL.

Proper milk standards, while they are essential to efficient milk control by public health authorities and have as their object the protection of the milk consumer, are also necessary for the ultimate well-being of the milk industry itself. Public confidence is an asset of the highest value in the milk business. The milk producer is interested in proper standards for milk, since these contribute to the control of bovine tuberculosis and other cattle diseases and distinguish between the good producer and the bad producer. The milk dealer is immediately classified by milk standards, either into a seller 
of first-class milk or a seller of second-class milk, and such distinction gives to the seller of first-class milk the commercial rewards which he deserves, while it inflicts just penalties on the seller of second-class milk. For milk consumers, the setting of definite standards accompanied by proper labeling makes it possible to know the character of the milk which is purchased and to distinguish good milk from bad milk. In the matter of public health administration, standards are absolutely necessary to furnish definitions around which the rules and regulations of city health departments can be drawn, and the milk supply efficiently controlled.

\section{PUBLIC HEALTH AUTHORITIES.}

While public health authorities must necessarily see that the source of supply and the chemical composition should correspond with established definitions of milk as a food, their most important duty is to prevent the transmission of disease through milk. This means the control of infantile diarrhea, typhoid fever, tuberculosis, diphtheria, scarlet fever, septic throat infections, and other infectious diseases in so far as they are carried by milk.

\section{SEPTIC SORE THROAT.}

Septic sore throat deserves special mention because of the frequency in recent years with which outbreaks of this disease have been traced to milk supplies. The suggestion has been made that the infection of the milk is due to udder infection of the cow and on the other hand it has been suggested that it is due to contact with infected persons. The uncertainty can not be dispelled until cases of septic sore throat are regularly reported and tabulated by public health authorities. The commission therefore recommends that public health authorities make septic sore throat a reportable disease.

\section{ECONOMIC PROBLEM.}

The commission recognizes the magnitude of the milk industry, and that the improvement of milk supplies is primarily an economic problem. The success achieved by the experiment in milk production, which has been carried out on a very large scale by the New York Dairy Demonstration Co., is an illustration of the fact that an extra price or premium paid to the producer for cleanliness and care will bring results far more quickly and certainly than instructions or official inspection. But while the basic problem is economic, and must eventually be solved by commerce, public health authorities must show the way and must establish standards and regulations in the interest of consumers, the value of which even the consumers themselves often fail to appreciate. 
A prime requisite of effectiveness is that local milk laws shall not exceed sanitary limitations. The commission has not entered into a discussion of fundamental State laws, but it recommends that State laws be amended wherever necessary in order that every municipality may have the legal right to adopt whatever ordinances it sees fit for the improvement of the milk supply. The commission advocates that local health laws be carefully drawn with regard to their legality under the general laws of the localities to which they apply, since a decision against a milk law in one locality is liable to be used as a precedent against milk laws elsewhere.

\section{STANDARD RULES AND REGULATIONS.}

The commission has drawn up a set of standard rules and regulations for the control of milk. These are the result of a study of the printed rules and regulations of the cities of the United States and of foreign countries and represent an immense amount of work on the part of the special committee of the commission to which the task was assigned. Some communities are in a position to adopt all of these rules and regulations at the present time, while other communities will be obliged to adopt a few rules at a time as public sentiment and local conditions warrant. It is realized that some of the rules may have to be modified to meet local conditions. It seems wise to the commission to divide the regulations into two parts: First, requirements, under which head are set down those provisions which are so fundamentally necessary that no community is justified in compromising on them; second, recommendations, under which head are set down provisions which are necessary for a good milk supply, but on which there can be a certain amount of latitude for compromise by those communities in which public sentiment is not ready to support more than a moderate degree of protection of human life.

\section{ADMINISTRATIVE EQUIPMENT.}

Another prime requisite is that the administrative departments shall be adequately equipped with men, money, and laboratory facilities. In smaller communities cooperation between local boards of health to the extent of exchanging reports would eliminate much duplication. Where a community can not maintain a laboratory it can enter into laboratory arrangements with other communities, and several can combine in the use of a common laboratory. Much of the expense of tuberculin testing can be borne by the National and State Governments. The commission is of the opinion that results can not be expected from laws where there is not sufficient appropriation and 
where there is no machinery for their enforcement. On this subject the commission passed a resolution as follows:

Whereas the appropriations generally made for the purposes of carrying on laboratory analyses of milk are now in most cases entirely inadequate: Therefore be it

Resolved, That this commission recommends for the consideration of the authorities concerned an appropriation of funds commensurate with the importance of laboratory methods, which are of paramount importance in the hygienic control of the milk supply.

\section{CLASSIFIOATION OF MILKS.}

There is no escape from the conclusion that milk must be graded and sold on grade, just as wheat, corn, cotton, beef, and other products are graded. The milk merchant must judge of the food value and also of the sanitary character of the commodity in which he deals. The high-grade product must get a better price than at present. The low-grade product must bring less. In separating milk into grades and classes the commission has endeavored to make its classification as simple as possible and at the same time to distinguish between milks which are essentially different in sanitary character.

In general two great classes of milk are recognized, namely, raw milk and pasteurized milk. Under these general classes there are different grades, as indicated in the report of the committee on classification.

\section{RE P O R T.}

\section{PASTEURIZATION.}

While the process of pasteurization is a matter which has attracted a great deal of attention in recent years, the commission has not entered into any discussion of its merits or demerits, but has given it recognition in its classification as a process necessary for the treatment of milk which is not otherwise protected against infection.

The commission thinks that pasteurization is necessary for all milk at all times, excepting grade $\mathrm{A}$, raw milk. The majority of the commissioners voted in favor of the pasteurization of all milk, including grade A, raw milk. Since this was not unanimous the commission recommends that the pasteurization of grade A, raw milk, be optional.

The process of pasteurization should be under official supervision. The supervision should consist of a personal inspection by the milk inspector; the inspections shall be as frequent as possible. Automatic temperature regulators and recording thermometers should be required and the efficiency of the process frequently determined by laboratory testing. 


\section{PASTEURIZING TEMPERATURES.}

The destruction of the chemical constituents of milk by heat occurs at higher temperatures than those necessary for the destruction of the bacteria of infectious diseases transmissible by milk. (See chart in appendix.)

The commission passed a resolution regarding the temperature of pasteurization as follows:

That pasteurization of milk should be between the limits of $140^{\circ} \mathrm{F}$. and $155^{\circ} \mathrm{F}$. At $140^{\circ} \mathrm{F}$. the minimum exposure should be 20 minutes. For every degree above $140^{\circ} \mathrm{F}$. the time may be reduced by $l$ ininute. In no case should the exposure be for less than 5 minutes.

In order to allow a margin of safety under commercial conditions the commission recommends that the minimum temperature during the period of holding should be made $145^{\circ} \mathrm{F}$. and the holding time 30 minutes. Pasteurization in bulk when properly carried out has proven satisfactory, but pasteurization in the final container is preferable.

It is the sense of the commission that pasteurization in the firal container should be encouraged.

\section{LABELING AND DATING OF MILK.}

The commission voted that all milk should bo labeled and marked with the grade in which it is to be sold. In dating milk uniform methods should be adopted for all grades of both raw milk and pasteurized milk, both using the day of the week or both using the day of the month. All milk should be dated uniformly with the date of delivery to the consumer. Raw milk should not be dated with the date of production while pasteurized milk is dated with the date of pasteurization, since this places certified milk at a disadvantage by making it possible for pasteurized milk of a lower grade to carry a later date. The stamping on the label of the day of the week is sufficient for dating.

\section{BACTERIA.}

The subject of bacteria in milk received more attention than any other matter brought before the commission. The commission recognizes that bacteria in milk in the majority of instances indicate dirt, or lack of refrigeration, or age, while in the minority of instances the bacteria of disease may be present. The routine laboratory methods for examining milk have as their purpose only the control over dirt, refrigeration, and age, and it is a rare thing for a laboratory to undertake the examination of milk for the bacteria of disease because of the extreme difficulties in detecting them. The more efficacious method of protecting milk from infection by the bacteria of human contagion is by medical, veterinary, and sanitary inspection, and by

$7045^{\circ}-13-2$ 
pasteurization. Milk with a high bacteria count is not necessarily harmful, but when used as a food, particularly for children, is a hazard too great to be warranted. Milk with a high bacteria count, therefore, should be condemned. Milks with small numbers of bacteria are presumed to be wholesome, unless there is reasonable ground for suspecting that they have been exposed to contagion.

\section{BACTERIAL STANDARDS.}

The commission recognizes the difficulty in interpreting bacteria counts. At times misleading conclusions have been drawn from such counts. In establishing the bacterial standards for a city it is always necessary to take into consideration the necessary age of the milk and in lesser measure the distance hauled and methods employed in its hauling. It will always be possible for a community which consumes milk produced on its own premises, or within 12 hours of its production, to insist upon and maintain a lower bacterial standard than can one where the milk is hauled many miles into town in a wagon, to be consumed within 24 hours after it is produced. In like manner this second type of city can always maintain a lower bacterial standard than a city where the general milk supply is hauled by railroad long distances and is several days old when consumed. In drawing conclusions as to the relative efficacy of milk control in cities comparisons must be made between cities of the same class.

The commission deems it of the utmost importance that some standard method should be adopted for estimating and comparing the bacterial character of milks, since by this means only is it possible to grade and classify milks and to enforce bacterial standards. There is much diversity of opinion as to the best method of valuing bacteria counts. The average of a series gives results which are misleading about as frequently as otherwise. In the average a single high figure may unduly overbalance a large number of exceedingly low counts. There are objections to the use of the "median" or middle number when the counts are arranged in order of size, for the reason that the middle figure does not distinguish between two groups in one of which there may be some very high counts above the median and in the other of which there are none. The method of dividing results into groups as recommended by the American Public Health Association, while a step in the right direction, is cumbersome and does not clearly indicate whether or not a milk conforms to a given bacterial standard.

The commission passed a resolution at its last meeting regarding the number of bacterial tests necessary to determine the grade into which a milk falls, as follows:

That the grade into which a milk falls shall be determined bacteriologically by at least five consecutive bacteria counts taken over a period of not less than one week nor more than one month, and at least 80 per cent (four out of five) must fall below the limit set for the grade for which the classification is desired. 


\section{I,ABORATORY EXAMINATIONS FOR BACTERIA.}

On the subject of laboratory examinations of milk for bacteria the commission passed the following resolutions:

1. That the interesț of public health demand that the control of milk supplies, both as to production and distribution, shall include regular laboratory examinations of milk by bacteriological methods.

2. That among present available routine laboratory methods for determining the sanitary quality of milk the bacteria count occupies first place.

3. That bacteriological standards should be a factor in classifying or grading milks of different degrees of excellence.

4. That in determining the grade or class of a raw milk the specimen taken for bacteriological examination should be of milk as offered for sale.

5. That there should be bacteriological standards for pasteurized milk which should

- require laboratory examination of samples immediately before pasteurization as well as of milk offered for sale.

6. That the bacteria count of milk indicates its quality and history as it is modified by contamination, handling, dirt, temperature, or age. A high count indicates the necessity of investigation and inspection.

7. That there be adopted as standards for making the bacteria count the standard methods of the American Public Health Association, laboratory section, recommending, however, the following amendments:

A. That the culture medium used for testing milk be identical in its composition and reaction with the culture medium used for the testing of water provided in the standard methods of water analyses of the American Public Health Association.

B. That incubation of plate cultures be made at $37^{\circ} \mathrm{C}$. for 48 hours.

The bacterial standards given in the report are the work of a special committee of bacteriologists who considered all of the bacterial standards now in use. It is believed that the standards suggested are fair and wise and give full consideration to the state of the industry and of public health control. The commission believes that the adoption and enforcement of these bacterial standards will be more effective than any other one thing in improving the sanitary character of public milk supplies. The enforcement of these standards can be carried out only by the regular and frequent laboratory examinations of milks for the numbers of bacteria they may contain.

\section{CHEMICAL STANDARDS}

The chemical standards suggested are the work of a special committee, composed of chemists, which has carefully considered the natural composition of milk and the Federal and State standards already established. The standard of 3.25 per cent fat and 8.5 per cent solids, not fat, here proposed is in accordance with the recommendations of the Association of Official Agricultural Chemists and has been adopted by the United States Department of Agriculture and by a larger number of States than has any other standard. The simplification of the Babcock test makes the determination of fats and solids not fat an easy procedure quickly applied. Such chemical 
examinations of milk can be readily adopted and executed by any health-board laboratory at a very moderate expense. It is believed that such chemical standards as are suggested will inflict no real hardship on the milk producers of this country and that the provision regarding substandard milks is a liberal one.

\section{MICROSCOPIC EXAMINATION OF MILK.}

Because of studies which have been made during the past year the commission thinks it wise to omit temporarily any definite statement on the subject of microscopical examination of milk, and the determination of pus and bacteria by sedimentation methods, until further studies have been made. A special subcommittee has been appointed for this purpose which will make studies during the present year and the commission will take action on this matter at one of its later meetings.

\section{MISLABELING.}

The commission resolved that the sale of milk which is mislabeled or misbranded shall be punished by suitable penalties.

\section{PUBLICITY.}

The commission fully considered the matter of the publication of laboratory examinations of milk by city and town health authorities. When proper standards and regulations are established and adequate facilities furnished for laboratory work, it is believed that the laboratory tests will give an index of the character of the milk delivered to the public by milk sellers which is entirely fair and impartial. There can be no objection to publicity under such circumstances. It is an advantage to the seller of high-grade milk. It is an advantage to the consumer who desires to select a high-grade milk. It has much educational value both to producer and consumer. Therefore the commission recommends "that the reports of laboratory analyses of milk made by departments of health be regularly published."

MEDICAL INSPECTION.

It is the sense of the commission that the medical inspection of dairy employees should be emphasized in all ways possible.

\section{MILK DEALER'S LICENSE.}

The commission resolved that a dealer shall be required to have a permit or license to sell any grade or class of milk and to use a label for such class or grade. Such permit or license shall be revoked and the use of the label forbidden when the local health authorities shall determine that the milk is not in the class or grade designated. 


\section{DESIGNATION OF GRADE.}

The commission resolved that the grade of milk shall be designated by letter. It is the sense of the commission that the essential part is the lettering and that all other words on the label are explanatory.

In addition to the letters of the alphabet, used on caps or labels, the use of other terms may be permitted so long as such terms are not the cause of deception.

Caps and labels shall state whether milk is raw or pasteurized. The letter designating the grade to which milk belongs shall be conspicuously displayed on the caps of bottles or the labels on cans.

\section{CLASSIFICATION OF MILK.}

It was resolved that the classification of milk contained in the first report of the commission be amended as follows:

Milk shall be divided into three grades, which shall be the same for both large and small cities and towns, and which shall be designated by the first three letters of the alphabet. The requirements shall be as follows:

GRADE A.

Raw milk.-Milk of this class shall come from cows free from disease as determined by tuberculin tests and physical examinations by a qualified veterinarian, and shall be produced and handled by employees free from disease as determined by medical inspection of a qualified physician, under sanitary conditions such that the bacteria count shall not exceed 100,000 per cubic centimeter at the time of delivery to the consumer. It is recommended that dairies from which this supply is obtained shall score at least 80 on the United States Bureau of Animal Industry score card.

Pasteurized milk.-Milk of this class shall come from cows free from disease as determined by physical examinations by a qualified veterinarian and shall be produced and handled under sanitary conditions such that the bacteria count at no time exceeds 200,000 per cubic centimeter. All milk of this class shall be pasteurized under official supervision, and the bacteria count shall not exceed 10,000 per cubic centimeter at the time of delivery to the consumer. It is recommended that dairies from which this supply is obtained should score 65 on the United States Bureau of Animal Industry score card.

The above represents only the minimum standards under which milk may be classified in grade $\mathrm{A}$. The commission recognizes, however, that there are grades of milk which are produced under unusually good conditions, in especially sanitary dairies, many of which are operated under the supervision of medical associations. Such milks clearly stand at the head of this grade.

\section{GRADE B.}

Milk of this class shall come from cows free from disease as determined by physical examinations, of which one each year shall be by a qualified veterinarian, and shall be produced and handled under sanitary conditions such that the bacteria count at no time exceeds $1,000,000$ per cubic centimeter. All milk of this class shall be pasteurized under official supervision, and the bacteria count shall not exceed 50,000 per cubic centimeter when delivered to the consumer. 
It is recommended that dairies producing grade B milk should be scored and that the health departments or the controlling departments, whatever they may be, strive to bring these scores up as rapidly as possible.

GRADE C.

Milk of this class shall come from cows free from disease as determined by physical examinations and shall include all milk that is produced under conditions such that the bacteria count is in excess of $1,000,000$ per cubic centimeter.

All milk of this class shall be pasteurized, or heated to a higher temperature, and shall contain less than 50,000 bacteria per cubic centimeter when delivered to the customer. It is recommended that this milk be used for cooking or manufacturing purposes only.

Whenever any large city or community finds it necessary, on account of the length of haul or other peculiar conditions, to allow the sale of grade C milk, its sale shall be surrounded by safcguards such as to insure the restriction of its use to cooking and manufacturing purposes.

\section{CLASSIFICATION OF CREAM.}

Cream should be classified in the same grades as milk, in accordance with the requirements for the grades of milk, excepting the bacterial standards which in 20 per cent cream shall not exceed five times the bacterial standard allowed in the grade of milk.

Cream containing other percentages of fat shall be allowed a modification of this required bacterial standard in proportion to the change in fat.

\section{CHEMICAL STANDARDS.}

Cow's mitk.-Standard milk should contain not less than 8.5 per cent of milk solids not fat and not less than 3.25 per cent of milk fat.

Skim milk.- Standard skim milk should contain not less than 8.75 per cent of milk solids.

Cream.- Standard cream contains not less than 18 per cent of milk fat and is free from all constituents foreign to normal milk. The percentage of milk fat in cream over or under that standard should be stated on the label.

Buttermilk.-Buttermilk is the product that remains when fat is removed from milk or cream, sweet or sour, in the process of churning. Standard buttermilk contains not less than 8.5 per cent of milk solids. When milk is skimmed, soured, or treated so as to resemble buttermilk, it should be known by some distinctive name.

\section{HOMOGENIZED MILK OR CREAM.}

The commission is of the opinion that in the compounding of milk no fats other than milk fats from the milk in process should be used and that no substance foreign to milk should be added to it. The commission is opposed to the use of condensed milk or other materials for the thickening of cream unless the facts are clearly set forth on 
the label of the retail package. Regarding the process of homogenizing, the commission resolved as follows:

That homogenized milk or cream should be so marked, stating the percentage of fat that it contains.

\section{ADJUSTED MILKS.}

On the question of milks and creams in which the ratio of the fats to the solids not fat has been changed by the addition to or subtraction of cream or milk fat the commission has hesitated to take a position. On the one hand they are in favor of every procedure which will increase the market for good milk and make the most profitable use of every portion of it. On the other, they recognize the sensitiveness of milk, the ease with which it is contaminated, and the difficulty of controlling, standardizing, skimming, homogenizing, souring, etc., so that contaminations do not occur and inferior materials are not used. On this subject the commission passed a resolution presented by a special committee as follows:

Milk in which the ratio of the fats to the solids not fat has been changed by the addition to or subtraction of cream should be labeled "adjusted milk"; the label should show the minimum guaranteed percentage of fat and should comply with the same sanitary or chemical requirements as for milk not so standardized or modified.

REGULATION OF MARKET MLK ON BASIS OF GUARANTEED PERCENTAGE COMPOSITION.

1. Sellers of milk should be permitted choice of one of two systems in handling market milk. Milk can be sold, first, under the regular standard, or, second, under a guaranteed statement of composition.

2. Any normal milk may be sold if its per cent of fat is stated. In case the per cent of fat is not stated, the sale will be regarded as a violation unless the milk contains at least 3.25 per cent of milk fat.

3. As a further protection to consumers, it is desirable that when the guaranty system is used there be also a minimum guaranty of milk solids not fat of not less than 8.5 per cent.

4. Dealers electing to sell milk under the guaranty system should be required to state conspicuously the guaranty on all containers in which such milk is handled by the dealer or delivered to the consumer.

5. The sale of milk on a guaranty system should be by special permission obtained from some proper local authority.

\section{EXTENSION WORK.}

The commission indorsed the efforts of the New York Milk Committee to obtain funds for the formation of a bureau of extension work, such bureau to act as a collecting station for information regarding standards and regulations as to milk adopted by cities and towns 
in the United States. The bureau should also furnish information to such cities and towns as appeal for aid in the adoption of milk standards and should conduct a constructive program by placing in the field a man who would visit communities interested in establishing milk standards; and it may use the members of the commission on milk standards for carrying on the work of the bureau so far as possible in their own localities.

\section{PREFACE TO APPENDIX.}

The commission has confined its report rather closely to the standard requirements for milk. These requirements can not be met unless proper measures are taken. For instance: The milk must be produced from healthy cows in clean surroundings, and must then be promptly chilled and kept cool thereafter. The handling at all points must be done by healthy employees - employees who are not carriers of contagion.

The report of the subcommittees on the methods of production, handling, and distribution, while not properly a part of the report itself, are set forth in the following appendix.

A P P E N D I X.

\section{Standard Rules for the Production, Handling, and Distribution of Milk.}

As a basis for the promulgation of rules and recommendations governing the production, handling, and distribution of milk, it is recognized that we have to deal with two kinds of milk, raw and pasteurized, although there may be several grades of each of these two kinds. In order for any grade to be safe, it is recommended that the regulations herein set forth under the heading "Requirements" should be enforced. The regulations herein set forth under the heading "Recommendations" should be adopted wherever practicable as a means of improving the milk supply above the actual point of safety. (The term "milk" shall be construed to include the fluid derivatives of milk wherever such construction of the term is applicable.)

\section{LICENSES.}

REQUIREMENTS.

No person shall engage in the sale, handling, or distribution of milk in - until he has obtained a license therefor from the health authorities. This license shall be renewed on or before the 1st day of of each year and may be suspended or revoked at any time for cause. 
RECOMMENDATIONS.

The application for the license shall include the following statements:

(1) Kind of milk to be handled or sold.

(2) Names of producers with their addresses and permit numbers.

(3) Names of middlemen with their addresses.

(4) Names and addresses of all stores, hotels, factories, and restaurants at which milk is delivered.

(5) A statement of the approximate number of quarts of milk, cream, buttermilk, and skim milk sold per day.

(6) Source of water supply at farms and bottling plants.

(7) Permission to inspect all local and out-of-town premises on which milk is produced and handled.

(8) Agreement to abide by all the provisions of State and local regulations.

\section{PERMITS.}

REQUIREMENTS.

No person snall engage in the production of milk for sale in nor shall any person engage in the handling of milk for shipment into - until he has obtained a permit therefor from the health authorities. This permit shall be renewed on or before the 1st day of - of each year and may be suspended or revoked at any time for cause.

\section{RAW MILK.}

COW STABLES.

REQUIREMENTS.

1. They shall be used for no other purpose than for the keeping of cows, and shall be light, well ventilated, and clean.

2. They shall be ceiled overhead if there is a loft above.

3. The floors shall be tight and sound.

4. The gutters shall be water-tight.

\section{RECOMMENDATIONS.}

1. The window area shall be at least 2 square feet per 500 cubic feet of air space and shall be uniformly distributed, if possible. If uniform distribution is impossible, sufficient additional window area must be provided so that all portions of the barn shall be adequately lighted.

2. The amount of air space shall be at least 500 cubic feet per cow, and adequate ventilation besides windows shall be provided.

3. The walls and ceilings shall be whitewashed at least once every six months, unless the construction renders it unnecessary, and shall be kept free from cobwebs and dirt.

4. All manure shall be removed at least twice daily, and disposed of so as not to be a source of danger to the milk either as furnishing a breeding place for flies or otherwise.

5. Horse manure shall not be used in the cow stable for any purpose. 


\section{MILK ROOM.}

REQUIREMENTS.

Every milk farm shall be provided with a milk room that is clean, light, and well screened. It shall be used for no other purpose than for the cooling, bottling, and storage of milk and the operations incident thereto.

\section{RECOMMENDATIONS.}

1. It shall have no direct connection with any stable or dwelling.

2. The floors shall be of cement or other impervious material, properly graded and drained.

3. It shall be provided with a sterilizer unless the milk is sent to a bottling plant, in which case the cans shall be sterilized at the plant.

4. Cooling and storage tanks shall be drained and cleaned at least twice each week.

5. All drains shall discharge at least 100 feet from any milk house or cow etable.

\section{COWS.}

REQUIREMENTS.

1. A physical examination of all cows shall be made at least once every six months by a veterinarian approved by the health authorities.

2. Every diseased cow shall be removed from the herd at once and no milk from such cows shall be offered for sale.

3. The tuberculin test shall be applied at least once a year by a veterinarian approved by the health authorities.

4. All cows which react shall be removed from the herd at once, and no milk from such cows shall be sold as raw milk.

5. No new cows shall be added to a herd until they have passed a physical examination and the tuberculin test.

6. Cows, especially the udders, shall be clean at the time of milking.

7. No milk that is obtained from a cow within 15 days before or 5 days after parturition, nor any milk that has an unnatural odor or appearance, shall be sold.

8. No unwholesome food shall be used.

\section{RECOMMENDATIONS.}

1. Every producer shall allow a veterinarian employed by the health authorities to examine his herd at any time under the penalty of having his supply excluded.

2. Certificates showing the results of all examinations shall be filed with the health authorities within 10 days of such examinations.

3 . The tuberculin tests shall be applied at least once every six months by a veterinarian approved by the health authorities, unless on the last previous test no tuberculosis was present in the herd or in the herds from which new cows were obtained, in which event the test may be postponed an additional six months.

4. Charts showing the results of all tuberculin tests shall be filed with the health authorities within 10 days of the date of such test.

5. The udders shall be washed and wiped before milking. 


\section{EMPLOYEES.}

REQUIREMENTS.

1. All employees connected in any way with the production and handling of milk shall be personally clean and shall wear clean outer garments.

2. The health authorities shall be notified at once of any communicable disease in any person that is in any way connected with the production or handling of milk, or of the exposure of such person to any communicable disease.

3. Milking shall be done only with dry hands.

RECOMMENDATIONG.

1. Clean suits shall be put on immediately before milking.

2. The hands shall be washed immediately before milking each cow, in order to avoid conveyance of infection to the milk.

\section{UTENSIIS.}

\section{REQUIREMENTS,}

1. All utensils and apparatus with which milk comes in contact shall be thoroughly washed and sterilized, and no milk utensil or apparatus shall be used for any other purpose than that for which it was designed.

2. The owner's name, license number, or other identification mark, the nature of which shall be made known to the health authorities, shall appear in a conspicuous place on every milk container.

3. No bottle or can shall be removed from a house in which there is, or in which there has recently been, a case of communicable disease until permission in writing has been granted by the health authorities.

4. All metal containers and piping shall be in good condition at all times. All piping shall be sanitary milk piping, in couples short enough to be taken apart and cleaned with a brush.

5. Small-top milking pails shall be used.

\section{RECOMMENDATIONS.}

1. All cans and bottles shall be cleaned as soon as possible after being emptied.

2. Every conveyance used for the transportation or delivery of milk, public carriers excepted, shall bear the owner's name, milk-license number, and business address in uncondensed gothic characters at least 2 inches in height. 
MILK.

REQUIREMENTS.

1. It shall not be strained in the cow stable, but shall be removed to the milk room as soon as it is drawn from the cow.

2. It shall be cooled to $50^{\circ} \mathrm{F}$. or below within two hours after it is drawn from the cow and it shall be kept cold until it is delivered to the consumer.

3. It shall not be adulterated by the addition to or the subtraction of any substance or compound, except for the production of the fluid derivatives allowed by law.

4. It shall not be tested by taste at any bottling plant, milk house, or other place in any way that may render it liable to contamination.

5. It shall be bottled only in a milk room or bottling plant for which a license or permit has been issued.

6. It shall be delivered in bottles, or single service containers, with the exception that 20 quarts or more may be delivered in bulk in the following cases:

(a) To establishments in which milk is to be consumed or used on the premises.

(b) To infant-feeding stations that are under competent medical supervision.

7. It shall not be stored in or sold from a living room or from any other place which might render it liable to contamination.

RECOMMENDATIONS.

1. It shall be cooled to $50^{\circ} \mathrm{F}$. or below immediately after milking and shall be kept at or below that temperature until it is delivered to the consumer.

2. It shall contain no visible foreign material.

3. It shall be labeled with the date of production.

\section{RECEIVING STATIONS AND BOTTLING PLANTS.}

REQUIREMENTS.

1. They shall be clean, well screened, and lighted, and shall be used for no other purpose than the proper handling of milk and the operations incident thereto, and shall be open to inspection by the health authorities at any time.

2. They shall have smooth, impervious floors, properly graded and drained.

3. They shall be equipped with hot and cold water and steam.

4. Ample provision shall be made for steam sterilization of all utensils, and no empty milk containers shall be sent out until after such sterilization.

5. All utensils, piping, and tanks shall be kept clean and shall be sterilized daily. 


\section{RECOMMENDATIONS.}

1. Containers and utensils shall not be washed in the same room in which milk is handled.

STORES.

REQUIREMENTS.

1. All stores in which milk is handled shall be provided with a suitable room or compartment in which the milk shall be kept. Said compartment shall be clean and shall be so arranged that the milk will not be liable to contamination of any kind.

2. Milk shall be kept at a temperature not exceeding $50^{\circ} \mathrm{F}$.

\section{RECOMMENDATIONS.}

1. Milk to be consumed off the premises may be sold from stores only in the original unopened package.

\section{GENERAL REGULATIONS.}

\section{REQUIREMENTS.}

1. The United States Bureau of Animal Industry score card shall be used, and it is recommended that dairies from which milk is to be sold in a raw state shall score at least 80 points.

2. Every place where milk is produced or handled and every conveyance used for the transportation of milk shall be clean.

3. All water supplies shall be from uncontaminated sources and from sources not liable to become contaminated.

4. The license or permit shall be kept posted in a conspicuous place in every establishment for the operation of which a milk license or permit is required.

5. No milk license or permit shall at any time be used by any person other than the one to whom it was granted.

6. No place for the operation of which a license or permit is granted shall be located within 100 feet of a privy or other possible source of contamination, nor shall it contain or open into a room which contains a water-closet.

7. No skim milk or buttermilk shall be stored in or sold from cans or other containers unless such containers are of a distinctive color and permanently and conspicuously labeled "skim milk" or "buttermilk," as the case may be.

8. No container shall be used for any other purpose than that for which it is labeled.

\section{RECOMMENDATIONS.}

1. Ice used for cooling purposes shall be clean and uncontaminated.

2. No person whose presence is not required shall be permitted to remain in any cow stable, milk house, or bottling room. 


\section{SUBNORMAL MILK.}

REQUIREMENTS.

1. Natural milk that contains less than 3.25 per cent, but more than 2.5 per cent milk fat, and that complies in all other respects with the requirements above set forth, may be sold, provided the percentage of fat does not fall below a definite percentage that is stated in a conspicuous manner on the container; and further provided that such container is conspicuously marked "substandard milk."

CREAM.

REQUIREMENTS AND RECOMMENDATIONS.

1. It shall be obtained from milk that is produced and handled in accordance with the provisions hereinbefore set forth for the production and handling of milk.

\section{STANDARDS FOR MILK.}

REQUIREMENTS.

1. It shall not contain more than 100,000 bacteria per cubic centimeter.

2. It shall contain not less than 3.25 per cent milk fat.

3. It shall contain not less than 8.5 per cent solids not fat. RECOMMENDATIONS.

1. The bacterial limit shall be lowered if possible.

\section{STANDARDS FOR CREAM.}

REQUIREMENTS.

1. There shall be a bacterial standard for cream corresponding to the grade of milk from which it is made and to its butter-fat content.

2. It shall contain not less than 18 per cent milk fat.

Same as above for milk.

RECOMMENDATIONS.

STANDARDS FOR SKIM MILK.

REQUIREMENTS.

1. It shall contain not less than 8.75 per cent milk solids.

2. Control of sale of skim milk: Whether skim milk is sold in wagons or in stores all containers holding skim milk should be painted some bright, distinctive color and prominently and legibly marked "skim milk." When skim milk is placed in the buyer's container, a label or tag bearing the words "skim milk" should be attached. 


\section{PASTEURIZED MILK.}

Pasteurized milk is milk that is heated to a temperature of not less than $140^{\circ} \mathrm{F}$. for not less than 20 minutes, or not over $155^{\circ} \mathrm{F}$. for not less than 5 minutes, and for each degree of temperature over $140^{\circ} \mathrm{F}$. the length of time may be 1 minute less than 20 . Said milk shall be cooled immediately to $50^{\circ} \mathrm{F}$. or below and kept at or below that temperature.

$$
\text { COW STABLES. }
$$

REQUIREMENTS.

The same as for the production of raw milk.

$$
\text { RECOMMENDATIONS. }
$$

The same as for the production of raw milk.

MILK ROOM.

REQUIREMENTS.

The same as for the production of raw milk.

$$
\text { RECOMMENDATIONS. }
$$

The same as for the production of raw milk.

cows.

REQUIREMENTS.

The same as for the production of raw milk, with the exception of the sections relating to the tuberculin test.

\section{RECOMMENDATIONS.}

That no cows be added to a herd excepting those found to be free from tuberculosis by the tuberculin test.

\section{EMPLOYEES.}

REQUIREMENTS.

The same as for the production of raw milk.

RECOMMENDATIONS.

The same as for the production of raw milk.

$$
\text { UTENSILS. }
$$

REQUIREMENTS.

The same as for the production of raw milk.

$$
\text { RECOMMENDATIONS. }
$$

The same as for the production of raw milk. 


\section{MILK FOR PASTEURIZATION.}

\section{REQUIREMENTS.}

1. The same as for the production of raw milk, with the exception of sections 1,2 , and $6 b$.

2. It shall be cooled to $60^{\circ} \mathrm{F}$. or below within two hours after it is drawn from the cow, and it shall be held at or below that temperature until it is pasteurized. After pasteurization, it shall be held at a temperature not exceeding $50^{\circ} \mathrm{F}$. until delivered to the consumer.

3. Pasteurized milk shall be distinctly labeled as such, together with the temperature at which it is pasteurized and the shortest length of exposure to that temperature and the date of pasteurization.

\section{RECOMMENDATIONS.}

1. No milk shall be repasteurized.

2. The requirements governing the production and handling of milk for pasteurization should be raised wherever practicable.

\section{PASTEURIZING PLANTS.}

REQUIREMENTS.

The same as under "Receiving stations and bottling plants" for raw milk.

$$
\text { RECOMMENDATIONS. }
$$

The same as under "Receiving stations and bottling plants" for raw milk.

STORES.

REQUIREMENTS

The same as for raw milk.

RECOMMENDATIONS.

The same as for raw milk.

GENERAL REGULATIONS.

REQUIRENENTS.

1. It is recommended that dairies producing milk which is to be pasteurized shall be scored on the United States Bureau of Animal Industry score card, and that health departments, or the controlling departments whatever they may be, strive to bring these scores up as rapidly as possible.

2. Milk from cows that have been rejected by the tuberculin test, but which show no physical signs of tuberculosis, as well as those which have not been tested, may be sold provided that it is produced and handled in accordance with all the other requirements herein set forth for pasteurized milk.

3. Ice used for cooling purposes shall be clean. 
RECOMMENDATIONS.

The same as for raw milk.

\section{PASTEURIZED CREAM.}

REQUIREMENTS.

1. It shall be obtained only from milk that could legally be sold as milk under the requirements hereinbefore set forth.

2. Pasteurized cream, or cream separated from pasteurized milk, shall be labeled in the manner herein provided for the labeling of pasteurized milk.

\section{STANDARDS FOR PASTEURIZED MILK.}

REQUIREMENTS.

1. It shall not contain more than $1,000,000$ bacteria per cubic centimeter before pasteurization, nor over 50,000 when delivered to the consumer.

2. The standards for the percentage of milk fat and of total solids shall be the same as for raw milk.

\section{RECOMMENDATIONS.}

1. The limits for the bacterial count before pasteurization and after pasteurization should both be lowered if possible.

\section{STANDARDS FOR PASTEURIZED CREAM.}

REQUIREMENTS.

1. No cream shall be sold that is obtained from pasteurized milk that could not be legally sold under the provisions herein set forth, nor shall any cream that is pasteurized after separation contain an excessive number of bacteria.

2. There shall be a bacterial standard for pasteurized cream corresponding to the grade of milk from which it is made and to its butterfat content.

3. The percentage of milk fat shall be the same as for raw cream. PENALTY.

Every milk ordinance should contain a penalty clause. 
TIME AND TEMPERATURE FOR

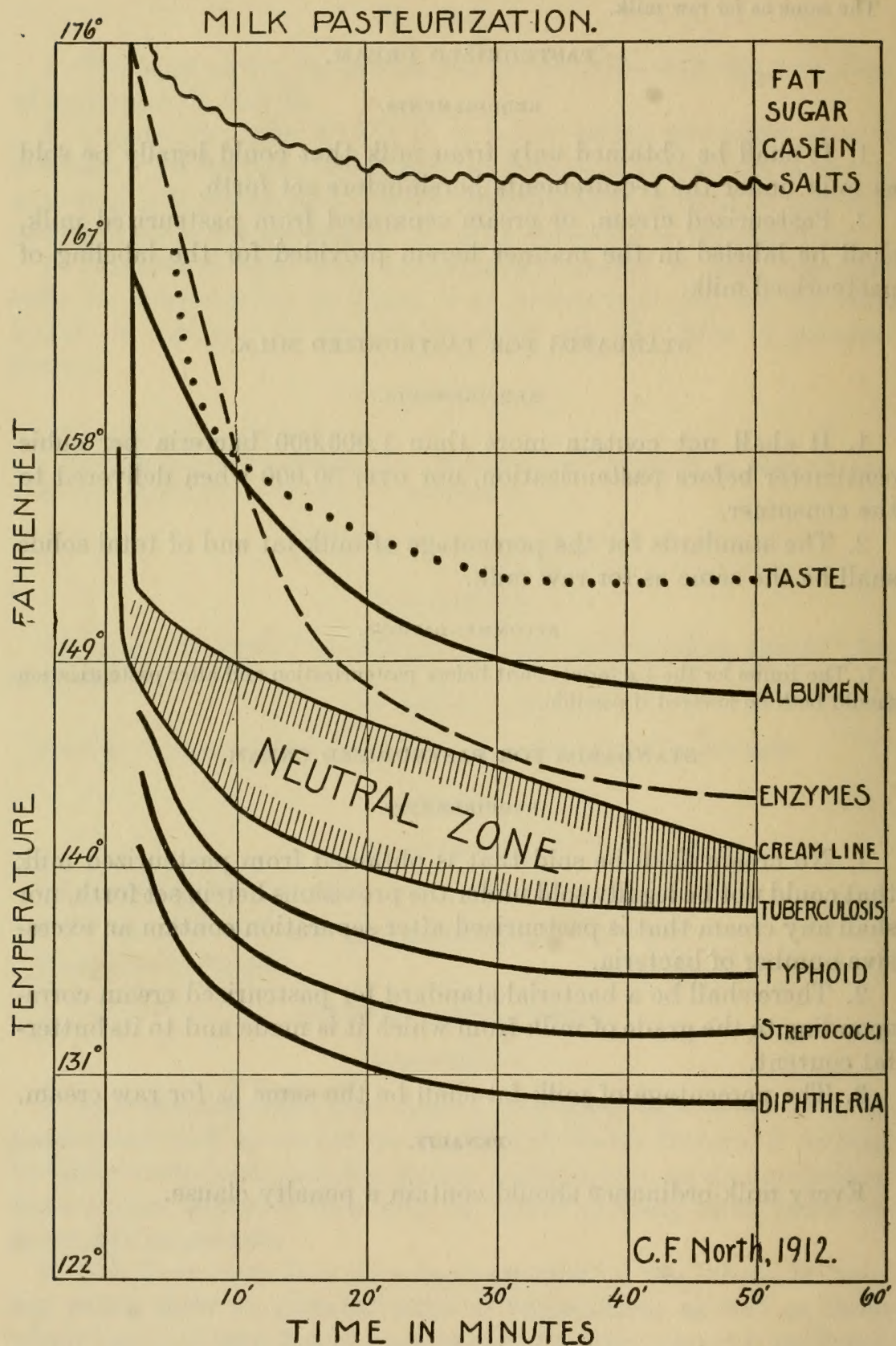

ADITIONAL COPIES of this publication $A$ may be procured from the SUPERINTENDENT OF DOCUMENTS, Government Printing Office, Washington, D. C. , at 5 cents per copy 



\section{LIBRARY OF CONGRESS}

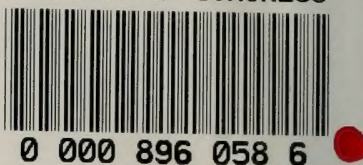

00008960586 